\title{
Regulation of Genetically Modified Food Use in the Russian Federation
}

\author{
Nadezhda V. Tyshko, Elvira 0. Sadykova \\ Federal State Budgetary Scientific Institution “Federal Research Centre of Nutrition, Biotechnology and Food \\ Safety", Moscow, Russian Federation \\ Email: tnv@ion.ru, seo@ion.ru
}

Received 27 May 2016; accepted 22 July 2016; published 25 July 2016

Copyright (C) 2016 by authors and Scientific Research Publishing Inc.

This work is licensed under the Creative Commons Attribution International License (CC BY). http://creativecommons.org/licenses/by/4.0/

(c) (i) Open Access

\section{Abstract}

Practical application of new methods of a plant genome transformation resulted in the need for strict regulation of the safety assessment process of genetically modified organisms of plant origin, intended for use in food. The devise of Genetically Modified Organisms (GMO) of plant origin safety assessment system, which is currently valid in the Russian Federation, was initiated in 19951996. Not only does the system accumulate all domestic and foreign experience, it also includes the latest scientific approaches, based on achievements of fundamental science. In the present article authors focused on issues of the basic legislative regulations of plant biotechnology in the Russian Federation, and approaches to the safety assessment of GM food and control over such food. GMO safety assessment is carried out at the stage of State registration. The subject of registration is novel food products derived from GMO, manufactured in the Russian Federation, as well as food products, entering the Russian Federation for the first time. In the system of medical and biological assessment of the GMO safety, along with general toxicological research, the study of specific types of toxicity in in vivo experiments takes a prominent place. In accordance with established research practice, which uses an integrated approach, and provides with the most complete and reliable information on potential reprotoxic, genotoxic, immunotoxic and allergenic effects of GMO, as well as enables to reveal possible unintended effects of genetic modification. From 1999 to $201622 \mathrm{GM}$ lines passed the entire cycle of medical-biological investigations. By 2016 there had been amassed scientific foundation on GMO safety, which includes the analysis of result of research, carried out within the framework of GMO state registration in the Russian Federation, as well as domestic and international data, presented by scientific literature on the problem of biotechnological food safety, at both registration stage and post-registration monitoring stage. To sum up, in the Russian Federation the most essential issues, allowing to use GMO for food purpose have been resolved: 1) legislation, normative and methodical foundations, regulating safety assessment and control over GMO turnover, as well as ensuring customer awareness about presence of GMO in food products, have been created; 2) scientifically proven evidence on the lack of negative effects for human health, i.e. GMO safety has been amassed; 3 ) the possibility of control over GMO turnover throughout the food market of the country has been sustained. 


\section{Keywords}

\section{Plant Biotechnology, GM Food, GMO Safety Assessment, GMO Legislative Regulation, GM Food Labelling, Control over GMO}

\section{Introduction}

Biotechnologies alongside with the information technology and nanotechnology are crucial elements of innovative development of modern economy. Analysis of domestic experience and global trends of biotechnologies development has revealed that so-called "Bioeconomy" is now forming in developed countries. The bioeconomy is based on the use of renewable raw materials, allowing both reducing dependence on natural resources and using the most environmentally and economically advantageous methods of farming under conditions of the global climate change. Biotechnology is beginning to play an increasing role in the development of new materials, and increase in agricultural productivity, environment protection, and improvement of the life quality in general.

The analysis of the current situation, being formed over the past few years, in the agro-industrial complex of the Russian Federation, points out at a decrease in the production of all types of agricultural products more than 1.5 times. Under the circumstances when total volume of natural and human resources remains, more than 30 million hectares of highly productive agricultural lands have been withdrawn from the turnover, and the productivity of agro-ecosystems is very low. According to experts, Russia appears to have missed the "green" wave of agro-biotechnological global revolution, and this has had a negative impact on the economic status and food security of the country. The total contribution of Russia to the world market of biotechnology today is estimated $0.2 \%$, and the country hasn't ever been presented on the market of GM crops [1]. The measures, having been taken so far in order to stabilize the situation on the agricultural market of Russia and to develop the foundation of food raw materials, have partially exhausted themselves, due to ineffectiveness and insufficiency. Therefore, there is a need for fundamentally new approaches to the devising of highly productive agricultural systems, which are to provide significant increase in crop yields and livestock productivity.

\section{Legislative Regulation of Plant Biotechnology in the Russian Federation}

Nowadays the use of up-to-date technologies, in particular, biotechnology, in the domain of providing country food supply, appears to be the one of state priorities in the Russian Federation. In order to execute this actual regulatory and methodical base was created.

-Federal Law "On the state regulation in the sphere of genetic engineering activities" (No 86-FZ from 05.07.1996);

-Federal Law “On the sanitary and epidemiological public wellbeing” (No 52-FZ from 30.03.1999);

-Federal Law "On the quality and safety of food products” (No 29-FZ from 02.01.2000);

-Federal Law "On the protection of consumers rights" (No 2300-1 from 07.02.1992);

-Decree of the President of the Russian Federation No 120 from January 30, 2010, "On approval of food security doctrine of the Russian Federation";

-Decree of the President of the Russian Federation No 899 from July 7, 2011, "On approval of the priority directions of science and technology development in the Russian Federation and the list of critical technologies of the Russian Federation";

-Resolution of the Russian Government No 717 from July 14, 2012, "On the state program for development of agriculture and regulation of agricultural and food markets in 2013-2020";

-Decree of the Government of the Russian Federation No 1873-r from October 25, 2010, "On approval of foundations of state policy in the field of healthy nutrition in the period up to 2020";

-Decree of the Government of the Russian Federation No 2237-r from December 3, 2012, "On Approval of the basic scientific research program of State Academies of Sciences for 2013-2020";

-“A comprehensive program of biotechnology development in the Russian Federation for the period till 2020", approved by Government of the Russian Federation No 1853p-P8 from April 24, 2012;

-Resolution of the Russian Government No 839 from September 23, 2013, "On the state registration of genetically-engineered-modified organisms intended for release into the environment as well as products derived with 
the use of such organisms or containing such organisms”;

-Resolution of the Russian Government No 548 from June 16, 2014, "On the amendments to the Resolution No 839 from September 23, 2013”;

-Methodical Guidelines 2.3.2.2306-07 "Medical and biological safety assessment of genetically modified organisms of plant origin";

-Methodical Guidelines 4.2.2304-07 "Methods of identification and quantitative determination of genetically modified organisms of plant origin";

-Methodical Guidelines 4.2.1903-04 "Food. Method identification of genetically modified sources (GMS) of plant origin with biological microchip";

-Methodical Guidelines 2.3.2.1917-04 "The procedure and organization of control over food products derived from/or with the use of raw materials of vegetable origin, having genetically modified counterparts";

-Methodical Guidelines 4.2.3105-13 "The procedure and methods of identification and quantitative determination of GMO, produced with the use of new biotechnology, in food products";

-Methodical Guidelines 4.2.3309-15 "Methods of identification and quantitative determination of new lines of 2nd generation GMO in food products";

-State standard of the Russian Federation (GOST R) 52173-2003 "Raw material and products. Method of identification of genetically modified (GMO) plant”;

-GOST R 52174-2003 "Biological safety. Raw materials and food products. Method of identification of genetically modified sources (GMS) of plant origin with the use of biological microchip";

-GOST R 53214-2008 (ISO 24276:2006) "Foodstuffs. Methods of analysis for the detection of genetically modified organisms and derived products. General requirements and definitions";

-GOST R 53244-2008 (ISO 21570:2005) "Foodstuffs. Methods of analysis for the detection of genetically modified organisms and derived products. Quantitative nucleic acid based methods";

-Methodical Guidelines 2.3.2.1830-04 "Microbiological and molecular-genetic evaluation of food products derived from genetically modified microorganisms";

-Methodical Guidelines 4.2.2305-07 "Detection of genetically modified microorganisms and microorganisms, which have genetically modified counterparts, in food by means of real-time polymerase chain reaction (PCR) and PCR with electrophoretic detection";

-Methodical Guidelines 2.3.2.2789-10 "Methodical guidelines for sanitary-epidemiological safety assessment and evaluation of functional capacity of probiotic microorganisms which are used for food production".

The purpose of development of biotechnologies in the Russian Federation is access to leading positions in the present field, including several directions of biomedicine, agrobiotechnologies, industrial biotechnology and bioenergy and devising of global competitive sector of bioeconomy, which alongside with nanoindustry and information technologies is supposed to become the foundation of modernization and building of postindustrial economy.

In the framework of realization of Complex program of biotechnologies development Resolution of Russian Federation Government No 839 from 23.09.2013 "On the state registration of genetically-engineered-modified organisms intended for release into the environment as well as products derived from the use of such organisms or containing such organisms" was passed. The Resolution determines federal authorities of executive power, which shell conduct state registration depending on target use of modified organism, and the order of GMO state registration, including the list of compulsory assessments, which must be carried out in the framework of preregistration investigations.

\section{The Milestones of Formation and Main Features of the Legislative Regulation}

In the present article the Russian approach to regulation of plant origin GMO use, proposed for food purpose, will be considered in detail. According to requirements of Russian State legislation at present time all aspects of regulation of GM food usage are assured, and include reliable system of medical-biological safety assessment; effective system of control of manufacturing and turnover; accessibility of information (labelling) regarding GMO usage while manufacturing of food products [2]-[5].

In the late 90-s of XX century with the efforts of Ministry of Healthcare, Federal Service for Surveillance on Consumer Rights Protection and Human Wellbeing (Rospotrebnadzor), Russian Academy of Medical Sciences (RAMS), Russian Academy of Agriculture Sciences, Russian Academy of Science (RAS) in the Russian Feder- 
ation the system of safety assessment and control of GMO was devised. It absorbed all achievements of global science and practice in this area as well as significant domestic experience, in particular, the experience of the USSR in the 60-70-s, when Russia took leader positions in the world in the field of industrial biotechnology [3].

In 1996 in the Russian Federation Federal Law No 86 from 05.07.1996 "On the state regulation in the sphere of genetic engineering activities” was passed, which regulates emerging relations while conducting genetic engineering in the field of nature management, environmental protection and environmental security providing. According to article 4 of the Law, one of the main tasks of state registration is the determination of mechanism, which sustains the safety of nationals and environment in the process of genetic engineering and the use of its results. According to article 11 of the Law “... product (service), received with the use of genetic engineering methods, must meet requirements of ecological safety, sanitary norms, Pharmacopoeia’s articles, compulsory requirements of State standards of the Russian Federation”.

Federal Law “On sanitary and epidemiological public well-being” No 52 from 30.03.1999 determined, that “... food products, food supplements, row materials, as well as materials and items which are in contact with them while manufacturing, storaging, transportation and end realization to customer must comply sanitary-epidemiological rules and standards...”. Hygienic criteria of quality and safety of food products are stated in Sanitary and epidemiological rules and standards "Hygienic requirements for safety and nutrition value of food products” (No 2.3.2. 1078-01). Article 43 of the present Federal Law determines subjects and procedure of state registration of substances and products. According to Paragraph 1 of the article, state registration is required for “... firstly implemented into manufacturing and never used earlier chemical, biological substances and compounds, manufactured on their basis, potentially harmful to humans, as well as several product assortment, including food products, firstly imported in the Russian Federation”.

Federal Law “On the quality and safety of food products” No 29 from 02.01.2000 doesn't detach food products and raw materials with the use of GMO into separate product group, which demands individual approach to quality and safety assessment for humans, however, article 10 of the present Low introduces the system of state registration of food products, materials and items. According to paragraph 1 article 10, registration is required for novel food products, materials and items, manufactured in the Russian Federation, to which genetically modified food sources relate. It was particularly emphasized, that imported food products, materials and items demand state registration before entering the territory of the Russian Federation.

As far as food products manufactured with the use of GMO are concerned, in the Russian Federation since 1995 while sanitary and epidemiological expertise of food product having GM counterparts, Ministry of Healthcare of the Russian Federation has introduced the requirement to declare use of genetic engineering technologies while manufacturing the products. In 1996-97 they started to devise the system of quality and safety assessment of GM food products, and the first experimental research was carried out [3] [5] [6]. In 1999 Resolution No 7 from 06.04.1999 “On procedure for sanitary assessment and registration of food derived from genetically modified sources” of the Chief State Sanitary Physician of the Russian Federation determined the order of registration of GM food sources, which was further replaced by Resolution No 14 from 08.11.2000 "On the procedures of sanitary and epidemiological expertise of food products from genetically modified sources”. In compliance with the order each GMO of plant origin, firstly entering the Russian market, requires sanitary and epidemiological expertise, which is conducted in three directions: medical and genetical assessment, medical and biological assessment, technological parameters assessment of products [7]-[15]. The expertise of GM food is executed on foundation of documents and materials, submitted by applicant, and on the basics of research, conducted in the Russian Federation. Conclusion on product safety is submitted to Rospotrebnadzor, which issues permission for GMO use in food industry and realization to customer, or well-grounded refusal in registration. The Resolution orders keeping Register of GM food products, having passed registration in the Russian Federation.

In 2000 Methodical Guidelines, which regulate execution of medical and biological research on GMO safety assessment for human health were passed by Ministry of Healthcare of the Russian Federation (Methodical Guidelines 2.3.2.970-00 "Medical and biological assessment of food products derived from genetically modified sources”). In 2007 the new edition of Methodical Guidelines, approved by Rospotrebnadzor came out (Methodical Guidelines 2.3.2.2306-07 "Medical and biological safety assessment of genetically-engineered and modified organisms of plant origin”).

Only products, which have passed through the full circle of research and which have been used without any restrictions over years in both country of origin (mainly the USA) and other countries as well, are allowed on the 
Russian Federation market.

Therefore, because of certain falling behind in the area of implementation of the latest biotechnology, Russia has the opportunity to use the data of post-registration monitoring, conducted in countries already using GMO in food.

\section{Involved Institutions}

The leading science and research institutions of the Russian Federation take part in the work on assuring safety of genetic engineering technologies:

- Federal State Budgetary Scientific Institution "Federal Research Centre of Nutrition, Biotechnology and Food Safety" (former Institute of Nutrition RAMS);

- Federal State Institution "Federal Research Centre "Fundamentals of Biotechnology" of the Russian (former Center "Bioengineering" RAS);

- Federal State Budgetary Scientific Institution “I. Mechnikov Research Institute of Vaccines and Sera”;

- Federal State Budgetary Institution "Research Zakusov Institute of Pharmakology”;

- Institute of Biomedical Chemistry;

- Federal Budgetary Establishment of Science "Federal Scientific Center of Hygiene named after F.F. Erisman” of the Federal Service for Supervision in Protection of the Rights of Consumer and Man Wellbeing;

- Federal State Institution of Science State Research Center for Applied Microbiology \& Biotechnology of the Federal Service for Supervision in Protection of the Rights of Consumer and Man Wellbeing;

- State Federal-Funded Educational Institution of Higher Professional Training I.M. Sechenov First Moscow State Medical University of the Ministry of Health of the Russian Federation;

- Federal Research Center of Epidemiology and Microbiology named after N. F. Gamaleya, Ministry of Health of the Russian Federation;

- Federal State Budget Scientific Institution “All-Russian Scientific and Research Institute for Grain and Products of its Processing";

- Moscow State University of Food Production.

\section{Approaches to the Safety Assessment of GM Food in the Russian Federation}

The Russian system of GMO safety assessment at present time appears to be one of the strictest in the world. Contrary to approaches, accepted in the European Union and in the USA, where while confirming substantial equivalence of GMO to its traditional counterpart, the range of investigations may be reduced, the Russian GM safety assessment includes execution of the whole range of investigations, where conducting of each one is compulsory. Starting from the point of forming Russian system of GMO safety assessment included mandatory execution of chronic toxicological experiment with the duration of not fewer than 180 days. The approach was accepted by EU since 2004, except that in the EU the research duration accounts 90 days only. Since 2011 safety assessment of novel GM lines in the framework of the state registration procedure in the Russian Federation also includes conducting of reproduction toxicity investigation in the extended experiments on generations [3] [13][15].

GMO safety assessment is conducted at the stage of state registration. The novel food, received from plant GMO origin, manufactured in the Russian Federation, as well as GMO, firstly imported into the Russian Federation, requires state registration.

Requirements for safety assessment execution are listed in Methodical Guidelines 2.3.2.2306-07 "Medical and biological safety assessment of genetically-engineered and modified organisms of plant origin".

Medical and biological safety assessment of food, received from GMO of plant origin, includes:

- expert analysis and assessment of data, submitted by applicant;

- expert analysis of methods of detection, identification and quantity evaluation of GMO in food;

- medical and genetical assessment;

- assessment of functional and technological properties;

- medical and biological investigation.

The range and amount of necessary research are determined on the basics of analysis of the information regarding the subject of registration, submitted by applicant, however the execution of each listed blocks of investigations is obligatory (Methodical Guidelines 2.3.2.2306-07). 
Toxicological tests are carried out on laboratory animals (Wistar rats, initial age 25 - 30 days), whose diet includes GMO under investigation (test group) and its traditional counterpart (control group) in maximal possible amount, which doesn't disbalance main food substances. Throughout the experiment the constant supervision over the integral (appearance, behavior, body weight, etc.), hematological, biochemical, morphological parameters is carried out, besides, the investigations of reproductive function, pre- and postnatal progeny development are conducted.

The remarkable feature of the GMO safety assessment system, approved in the Russian Federation, is the use of parameters (sensitive biomarkers), reflecting the adaptation level of an organism to the environment and showing high sensitivity to xenobiotic influence [3]. Special attention is paid to the systems, which provide the protection of an organism from the impact of toxic compounds of exogenous and endogenous origins: the system of xenobiotic metabolism enzymes, the system of apoptosis regulation, the system of antioxidant protection.

In medical-biological investigations of plant GMO safety assessment, alongside with general toxicological research, the studying of specific types of toxicity in the in vivo experiments takes a prominent place.

According to commonly accepted research practice the complex approach, which providing the most trustworthy and complete information about potential genotoxic, immunotoxic and allergenic action of GMO, as well as allowing to detect possible unintended effects of genetic modification, is used [16]-[19]. Therefore the investigation of genotoxic action of GMO includes the assessment of genetic material condition at different structural levels (DNA molecules chromosomes); studying of immunotoxic action includes assessment of immunomodulating and sensitizing GMO properties in the experiment on opposite reacting mice lines; studying of allergenic action includes the assessment of severity of acute anaphylactic shock and intensity of humoral immune response on the model of system anaphylaxis in rats. In case of detection of significant change in genome, proteome, metabolome of GMO, additional research shell be conducted, when required [3].

The decision about state registration of plant GMO in the Russian Federation is based on the total amount of expert assessment of materials, submitted by applicant, of results of complex medical-biological safety assessment, medical-genetical and technological assessment, as well as expert assessment of GMO identification methods.

\section{The Approach to GM Food Labelling}

The approach to GM food labelling is carried out in compliance with legislation requirements of the Russian Federation and current international norms. The labelling introduced in 1999 as advisable measure (Resolution of the Chief State Sanitary Physician of the Russian Federation No 13 from April 08, 1999), by 2002 became obligatory. The level established by it decreased from 5\% in 2002 to $0.9 \%$ in 2007, becoming the norm, harmonized with the identical one in the EU countries (Sanitary and epidemiological rules and standards No 2.3.2.2227-07, FZ “On amending the law of the Russian Federation 'On Protection of Consumers' Rights” No 234-FZ from October 25, 2007, Customs Union Technical Regulation No 022/2011 on Food Labeling).

\section{The System of Control over GMO Turnover}

Under the conditions of global trend of increasing of plant GMO use, the system of control over GMO turnover ensures the maintenance of required security level of the country. The system of control over GMO turnover on the food market in the Russian Federation was devised on the foundation of fundamental research, conducted by Russian Academies of Sciences and implemented in the routine practice of Rospotrebnadzor, agricultural complex, custom service and other concerned authorities.

The methodical base includes the most up-to-date methods, based on polymerase chain reaction (PCR), the method of hybridization on biological microchip, real time PCR, immunofluorescence assay. In 2003-2015 alone more than 350,000 investigations of food for the purpose of GMO detection were carried out by the authorities of Rospotrebnadzor.

According to current requirements, valid throughout Customs Union (CU), it is forbidden to use GMO in baby food and child nutrition, dietary therapeutic and prophylactic nutrition (CU Technical Regulation "On Food Safety” No 021/2011). In accordance with the Technical Regulations provided that GM concentration per single ingredient accounts less than $0.9 \%$, GMO is accidental or technically nonremovable impurity, consequently such food is not considered to be GM-containing food. 


\section{Conclusions}

From 1999 to 201622 GM lines passed the entire cycle of medical and biological investigations [20]. By 2016 there had been amassed scientific foundation on GMO safety, which includes the analysis of result of research, carried out within the framework of GMO state registration in the Russian Federation, as well as domestic and international data, presented by scientific literature on the problem of biotechnological food safety, at both registration stage and post-registration monitoring stage.

To sum up, in the Russian Federation the most essential issues, allowing to use GMO for food purpose have been resolved: 1) legislation, normative and methodical foundations, regulating safety assessment and control over GMO turnover, as well as ensuring customer awareness about presence of GMO in food products, have been created; 2) scientifically proven evidence on the lack of negative effects for human health, i.e. GMO safety has been amassed; 3) the possibility of control over GMO turnover throughout the food market of the country has been sustained.

It is understood that the science is always on the move; intensive work on methodical foundation optimization, the use of cutting edge of scientific developments, and global information exchange, all provide confidence in look-ahead progress of scientific knowledge, particularly, for the purpose of assuring safety of novel food.

\section{References}

[1] BioTech 2030 (2016) Strategic Research Agenda of the Technological Platform 2030. http://biotech2030.ru/wp-content/uploads/2015/02/SPI aktualizatsiya 2008 2015.pdf

БиоТех 2030 (2016) Стратегическая программа исследований Технологической платформы 2030. http://biotech2030.ru/wp-content/uploads/2015/02/SPI_aktualizatsiya_20_08_2015.pdf

[2] Tutelyan, V.A. (2007) Genetically Modified Food Sources: Assessment of Safety and Control. Publisher RAMS, Moscow.

Тутельян, В.А. (ред.) (2007) Генетически модифицированные источники пищи: оценка безопасности и контроль. Издательство РАМН, Москва.

[3] Tutelyan, V.A. (2013) Genetically Modified Food Sources: Safety Assessment and Control. Elsevier Inc., Academic Press.

[4] Tyshko, N.V., Aksyuk, I.N. and Tutelyan, V.A. (2007) Safety Assessment of Genetically Modified Organisms of Plant Origin in the Russian Federation. Biotechnology Journal, 2, 826-832. http://dx.doi.org/10.1002/biot.200700020

[5] Onishchenko, G.G. (2015) Security Problems of Modern Bio- and Nanotechnology. Medicine Tidings, 2, 2-5. Онищенко, Г.Г. (2015) Проблемы безопасности современных био- и нанотехнологий. Вести медицины, 2, 2-5.

[6] Onischenko, G.G., Tutelyan, V.A., Petukhov, A.I., Korolyev, A.A., Aksyuk, I.N. and Sorokina, E.Yu. (1999) Current Approaches to Evaluation of Safety of Genetically Modified Food Products. Soybeans 40-3-2 Data. Voprosy Pitaniia (Problems of Nutrition), 68, 3-7.

Онищенко, Г.Г., Тутельян, В.А., Петухов, А.И., Королев, А.А., Аксюк, И.Н., Сорокина, Е.Ю. (1999) Современные подходы к оценке безопасности генетически модифицированных источников пищи. Опыт изучения соевых бобов линии 40-3-2. Вопросы питания, 68, 3-7.

[7] Tutelyan, V.A., Gapparov, M.M.G., Avrenjeva, L.I., Aksyuk, I.N., Guseva, G.V., Kravchenko, L.V., Lvova, L.S., Saprikin, V.P., Tyshko, N.V. and Chernysheva, O.N. (2008) Medical and Biological Safety Assessment of Genetically Modified Maize Event MON 88017. Report 1. Toxicologo-Hygienic Examinations. Voprosy Pitaniia (Problems of Nutrition), 77, 4-12.

Тутельян, В.А., Гаппаров, М.М., Авреньева, Л.И., Аксюк, И.Н., Гусева, Г.В., Кравченко, Л.В., Львова, Л.С., Сапрыкин, В.П., Тышко, Н.В., Чернышева, О.Н. (2008) Медико-биологическая оценка безопасности генноинженерно-модифицированный кукурузы линии MON 88017. Сообщение 1. Токсиколого-гигиенические исследования. Вопросы питания, 77, 4-12.

[8] Tyshko, N.V., Britsina, M.V., Gmoshinskii, I.V., Zhanataev, A.K., Zaharova, N.S., Zorin, S.N., Mazo, V.K. and Semenov, B.F. (2008) Medical and Biological Safety Assessment of Genetically Modified Maize Event MON 88017. Report 2. Genotoxicologic, Immunologic and Allergologic Examinations. Voprosy Pitaniia (Problems of Nutrition), 77, $13-17$.

Тышко, Н.В., Брицина, М.В., Гмошинский, И.В., Жанатаев, А.К., Захарова, Н.С., Зорин, С.Н., Мазо, В.К., Семенов, Б.Ф. (2008) Медико-биологическая оценка безопасности генно-инженерно-модифицированной кукурузы линии MON 88017. Сообщение 2. Генотоксикологические, иммунологические и аллергологические исследования. Вопросы питания, 77, 13-17.

[9] Tutelyan, V.A., Gapparov, M.M.G., Avrenjeva, L.I., Aksyuk, I.N., Guseva, G.B., Kravchenko, L.V., Lvova, L.S., Sa- 
prikin, V.P., Tyshko, N.V. and Chernysheva, O.N. (2009) Medical and Biological Safety Assessment of Genetically Modified Maize Event MIR604. Report 1. Toxicologo-Hygienic Examinations. Voprosy Pitaniia (Problems of Nutrition), 78, 24-32.

Тутельян, В.А., Гаппаров, М.М., Авреньева, Л.И., Аксюк, И.Н., Гусева, Г.В., Кравченко, Л.В., Львова, Л.С., Сапрыкин, В.П., Тышко, Н.В., Чернышева, О.Н. (2009) Медико-биологическая оценка безопасности генноинженерно-модифицированной кукурузы линии MIR604. Сообщение 1. Токсиколого-гигиенические исследования. Вопросы питания, 78, 24-32.

[10] Tyshko, N.V., Britsina, M.V., Gmoshinskii, I.V., Zhanataev, A.K., Zaharova, N.S., Zorin, S.N., Mazo, V.K., Ozerethskovskaya, M.N. and Semenov, B.F. (2009) Medical and Biological Safety Assessment of Genetically Modified Maize Event MIR604. Report 2. Genotoxicologic, Immunologic and Allergologic Examinations. Voprosy Pitaniia (Problems of Nutrition), 78, 33-38.

Тышко, Н.В., Брицина, М.В., Гмошинский, И.В., Жанатаев, А.К., Захарова, Н.С., Зорин, С.Н., Мазо, В.К., Озерецковская, М.Н., Семенов, Б.Ф. (2009) Медико-биологическая оценка безопасности генно-инженерномодифицированный кукурузы линии MIR604. Сообщение 2. Генотоксикологические, иммунологические и аллергологические исследования. Вопросы питания, 78, 33-38.

[11] Tutelyan, V.A., Gapparov, M.M.G., Avrenjeva, L.I., Guseva, G.V., Zhminchenko, V.M., Kravchenko, L.V., Pashorina, V.A., Saprikin, V.P., Seliaskin, K.E. and Tyshko, N.V. (2010) Medical and Biological Safety Assessment of Genetically Modified Soybean Event MON 89788. Report 1. Toxicologo-Hygienic Examinations. Voprosy Pitaniia (Problems of Nutrition), 79, 4-12.

Тутельян, В.А., Гаппаров, М.М.Г., Авреньева, Л.И., Гусева, Г.В., Жминченко, В.М., Кравченко, Л.В., Пашорина, В.А., Сапрыкин, В.П., Селяскин, К.Е., Тышко, Н.В. (2010) Медико-биологическая оценка безопасности генно-инженерно-модифицированной сои линии МON 89788. Сообщение 1. Токсиколого-гигиенические исследования. Вопросы питания, 79, 4-12.

[12] Tyshko, N.V., Britsina, M.V., Gmoshinskii, I.V., Zaharova, N.S., Zorin, S.N., Mazo, V.K., Ozerethskovskaya, M.N. and Seliaskin, K.E. (2010) Medical and Biological Safety Assessment of Genetically Modified Soybean Event MON 89788. Report 2. Genotoxicologic, Immunologic and Allergologic Examinations. Voprosy Pitaniia (Problems of Nutrition), 79, 13-17.

Тышко, Н.В., Брицина, М.В., Гмошинский, И.В., Захарова, Н.С., Зорин, С.Н., Мазо, В.К., Озерецковская, М.Н., Селяскин, К.Е. (2010) Медико-биологическая оценка безопасности генно-инженерно-модифицированной сои линии MON 89788. Сообщение 2. Генотоксикологические, иммунологические и аллергологические исследования. Вопросы питания, 79, 13-17.

[13] Tyshko, N.V., Zhminchenko, V.M., Pashorina, V.A., Saprykin, V.P., Selyaskin, K.E., Utembaeva, N.T. and Tutelyan, V.A. (2011) Evaluation of the Effect of Genetically Modified Plants on Rat Progeny Development. Hygiene and Sanitary (Gigiena i Sanitaria), 6, 73-77.

Тышко, Н.В., Жминченко, В.М., Пашорина, В.А., Сапрыкин, В.П., Селяскин, К.Е., Утембаева, Н.Т., Тутельян, В.А. (2011) Оценка влияния ГМО растительного происхождения на развитие потомства крыс. Гигиена и санитария, 6, 73-77.

[14] Tyshko, N.V., Zhminchenko, V.M., Pashorina, V.A., Saprikin, V.P., Selyaskin, K.E., Utembaeva, N.T. and Tutelyan, V.A. (2011) Assessment of the Impact of GMO of Plant Origin on Rat Progeny Development in Three Generations. Voprosy Pitaniia (Problems of Nutrition), 80, 14-28.

Тышко, Н.В., Жминченко, В.М., Пашорина, В.А., Сапрыкин, В.П., Селяскин, К.Е., Утембаева, Н.Т., Тутельян В.А. (2011) Оценка влияния ГМО растительного происхождения на развитие потомства крыс в трех поколениях. Вопросы питания, 80, 14-28.

[15] Tyshko, N.V., Zhminchenko, V.M., Selyaskin, K.E., Pashorina, V.A., Utembaeva, N.T. and Tutelyan, V.A. (2014) Assessment of the Impact of Genetically Modified LibertyLink ${ }^{\circledR}$ Maize on Reproductive Function and Progeny Development of Wistar Rats in Three Generations. Toxicology Reports, 1, 330-340. http://dx.doi.org/10.1016/j.toxrep.2014.05.013

[16] OECD (2000) Report of the Task Force for the Safety of Novel Foods and Feeds for the G8 Summit (Okinawa), OECD, Paris, C(2000)86/ADD1.

http://www.oecd.org/chemicalsafety/biotrack/REPORT-OF-THE-TASK-FORCE-FOR-THE-SAFETY-OF-NOVEL.pdf

[17] FAO (2001) Report of a Joint FAO/WHO Expert Consultation on Allergenicity of Foods Derived from Biotechnology: Evaluation of Allergenicity of Genetically Modified Foods, FAO, Rome. http://www.who.int/foodsafety/publications/ec 2001.pdf?ua=1

[18] EFSA (2008) Opinion of the Scientific Panel on Genetically Modified Organisms on Application (Reference EFSAGMO-NL-2006-36) for the Placing on the Market of the Glyphosate-Tolerant Genetically Modified Soybean MON89788, for Food and Feed Uses, Import and Processing under Regulation (EC) No 1829/2003 from Monsanto. The EFSA Journal, 758, 1-23.

[19] Habriev, R.U. (2005) Guideline for Experimental (Preclinical) Studying of New Pharmacological Substances. 2nd 
Edition, Medicine, Moscow.

Хабриев, Р.У. (ред.) (2005) Руководство по экспериментальному (доклиническому) изучению новых фармакологических веществ, 2-е издание, Медицина, Москва.

[20] Rospotrebnadzor (2016) The Register of State Registration Certificates (the Unified Form of the Customs Union, the Russian Part). http://fp.crc.ru/evrazes/

Роспотребнадзор (2016) Реестр свидетельств о государственной регистрации (единая форма Таможенного союза, российская часть). http://fp.crc.ru/evrazes/

\section{Submit or recommend next manuscript to SCIRP and we will provide best service for you:}

Accepting pre-submission inquiries through Email, Facebook, Linkedin, Twitter, etc A wide selection of journals (inclusive of 9 subjects, more than 200 journals)

Providing a 24-hour high-quality service

User-friendly online submission system

Fair and swift peer-review system

Efficient typesetting and proofreading procedure

Display of the result of downloads and visits, as well as the number of cited articles

Maximum dissemination of your research work

Submit your manuscript at: http://papersubmission.scirp.org/ 